\title{
Information Technology-based Innovation in International Marketing Education: An Exploration of Two Learning Environments
}

\author{
RUDOLF R. SINKOVICS \\ The University of Manchester, Manchester, UK \\ PARISSA HAGHIRIAN \\ Sophia University, Tokyo, Japan \\ SHASHA YU \\ The University of Manchester, Manchester, UK
}

\begin{abstract}
Information technology (IT) innovations have and continue to have a significant impact on international marketing practice and customer interactions. With the marketing environment becoming increasingly dependent on technology, marketing teaching in bigher education faces a challenging task of effectively leveraging technology in diverse learning environments. This article investigates key developments of recent years and explores drivers of learners' satisfaction within two different IT-based learning environments. Both virtual classrooms via video conferencing technology and the use of simulations for testing international marketing campaigns will be investigated. Factors which contribute to successful teaching outcomes by means of these technologies are identified. A learner satisfaction model for IT-based learning environments is used for identification of these factors and recommendations for marketing educators based on the evaluation of the results are given.
\end{abstract}

Submitted: July 2008; first revision: September 2008; second revision: October 2008; accepted December 2008

The authors gratefully acknowledge the comments and support from Bernd Simon on an earlier version of this manuscript.

Address correspondence to Rudolf R. Sinkovics, Reader in International Business, The University of Manchester, Manchester Business School, Booth Street West, Manchester M15 6PB, UK. E-mail: Rudolf.Sinkovics@mbs.ac.uk 
KEYWORDS virtual classroom, computer simulation, marketing education, student satisfaction

\section{INTRODUCTION AND RESEARCH BACKGROUND}

In modern pedagogy, Information Technology (IT) is an important technological development in the wider society and increasingly shapes the nature of marketing education (Beller \& Or, 1998; Russow, 2003; Schutte, 1999). Although some IT has long been adopted for teaching related tasks such as word processing and data storage, the waves of innovation have shifted from these support functions toward more fundamental changes (Celsi \& Wolfinbarger, 2002; Wymbs \& Kijne, 2003). Specifically, these changes both complement and challenge the traditional classroom method of teaching (Beller \& Or; Clark, Flaherty, \& Mottner, 2001; Russow, 2003; Schulman \& Randi, 1999; Schutte). In terms of complementarity, IT provides instructors with the opportunity for improved and more effective teaching through electronic integration of materials, and students with accessibility to a variety of knowledge databases and frequent interaction with instructors and peers (Beller \& Or). In terms of challenges, off-campus learning opportunities become prominent; e.g., by 1997, over 150 accredited institutions in North America offered entire degree programs online without the need to visit campus (Herther, 1997) and the number of institutions adopting such programs has increased dramatically in the new millenium. The incorporation of video films, multimedia courseware, and live lessons delivered to remote locations (including other countries) have made synchronous and asynchronous distance learning both viable and effective (Beller \& Or; Herther). Moreover, one key characteristic of IT enabled teaching is the potential to minimize physical-distance barrier and introduce the international dimension to the learning process where students located internationally or from diverse backgrounds can learn from peers through exchanging ideas (Klein, Gauthier, Mayon-White, \& Rajkovic, 2001; Young, 2000). Particularly, one curriculum is prominently influenced by IT innovations: international marketing (Celsi \& Wolfinbarger; Clark III et al., 2001; Ferrell, 1995; Hunt, Eagle, \& Kitchen, 2004; Peterson, Albaum, Munuera, \& Cunningham, 2002; Simon, Haghirian, \& Schlegelmilch, 2003).

As globalization forces continue, international marketing curricula enjoy a heightening profile both academically and commercially as we observe an increasing number of learners attracted to the subject around the globe (O'Brien \& Deans 1995). From students' viewpoint, they are aware of future employers' expectations of having a broad-based qualification and sound business knowledge. This subject's inherent flexibility offers them the opportunity to specialize on several areas of the curriculum, and provides 
better job prospects (Catterall, Maclaran, \& Stevens, 1999; O’Brien \& Deans). Hence, the significance of this subject has led institutions to face the challenge of fulfilling students' learning and career needs. However, conventional marketing education methods have been somewhat criticized for its under achievement of educational goals and employers' satisfaction (Middleton \& Long, 1990; O’Brien \& Deans).

Pedagogically, in traditional international marketing classes, the link between theoretical frameworks and their business applications are managed using assignment questions, examples in texts, case studies, guest speakers, or integrating business projects into the curriculum (BenbunanFich \& Hiltz, 1999; Benbunan-Fich \& Stoever, 2003). In more recent years, instructors have often used IT as a platform to allow students to bridge conceptual and theoretical underpinnings and their application to the "real world" (Blake \& Jarvenpaa, 1996). Leidner and Jarvenpaa (1995) argue that IT increases the sharing and construction of knowledge. Thus, the use of IT innovations can create a rich set of new educational opportunities (Alavi, Yoo, \& Vogel, 1997; Garrison, 2000; Meier \& Simon, 2000; Webster \& Hackley, 1997), especially for international marketing, where real examples play an enormous role and student participation is encouraged to enhance transferable skills and marketing competencies in a multicultural environment (Bell, Deans, Ibbotson, \& Sinkovics, 2001; Ueltschy, 2001; Wymbs \& Kijne, 2003).

Apart from the traditional classroom teaching of international marketing courses, IT has often acted as another channel to support pedagogical goals and fulfill requests regarding applied and hands-on education from future employers (Clark et al., 2001; Hunt et al., 2004). Particularly, employers often lament the lack of practical skills, an overemphasis of theory (O'Brien \& Deans, 1995), and largely philosophical speculation in university courses. IT can be a powerful means to offset such criticism by integrating real-world experiences into teaching and learning processes (Celsi \& Wolfinbarger, 2002), promoting international and multicultural issues (Benbunan-Fich \& Stoever, 2003), and providing a creative and cost-effective manner for internationalizing the curriculum (Bell et al., 2001). Following Kolb's (1984) experiential learning theory, IT allows to put together a greater variety of learning experiences into the curriculum. Kolb's view implies that students' comprehension of abstract ideas will be facilitated by immersing them in direct experiences that demonstrate the utility of the concepts taught (Alderfer 2003). Kolbs' cycle of experiential learning consists of four stages: concrete experience, observation and reflection, abstract conceptualization, and active experimentation. Firstly, the learners are involved in the concrete experience. In the next stage they reflect and process the information received during this experience. In stage 3 these experiences urge them to create new concepts, and finally, the learners use the generalizations derived 
from the three stages to develop strategies and guidelines for similar but maybe more complex situations.

In doing so, the learner gains a clear idea about the learning experience and knowledge about how to transform it into strategies and activities. ITmediated teaching can strongly support these learning processes, by providing actual experience-based learning and assessments. Hence, transferable skills such as teamwork, problem solving, and negotiationwhich are increasingly sought after by employers (O'Brien \& Deans, 1995) _ can be trained. IT further supports introducing a practice oriented and critical approach toward marketing theories, which will produce more reflexive marketing practitioners in the future (Catterall, Maclaran, \& Stevens, 1999).

Clearly, IT has been recognized as a crucial factor in modern education, particularly in improving international marketing teaching; however, its integration into the curriculum is by no means a trivial task (Arbaugh, 2001; Celsi \& Wolfinbarger, 2002; Hunt, Eagle, \& Kitchen, 2004; Peterson et al., 2002; Scheuermann, Larsson, \& Toto, 2001; Simon et al., 2003; Song, Singleteon, Hill, \& Koh, 2004). As far as instructors are concerned, a significant amount of extra preparation plus strong interests in modern educational technologies are required. Students are similarly challenged when IT is unfamiliar and not properly introduced into the learning environment or technological hiccups occur, which can cause paramount frustrations and minimum learning outcomes. Therefore, recommendations are required on how to apply IT-based learning environments effectively into the international marketing curriculum. Guidelines of how to exploit these opportunities when confronted with real-world marketing and management tasks are needed (Manning, Cohen, \& DeMichiell, 2003; Smart, Kelley, \& Conant 1999). These guidelines will not only support instructors, but also link closely to practitioners' needs for competent future employees.

In response to this call, this article aims at supporting educators to focus on relevant aspects in designing IT-based learning environments for teaching international marketing. We investigate the implementation of these tools from a students' perspective. Specifically, we analyze antecedents influencing students' satisfaction with IT-based marketing teaching. Two popular methods are discussed. Specifically, we take a conceptual look into realizing virtual classrooms via video conferencing technology and computer simulations for trialing international marketing campaigns. Then, we empirically investigate antecedents for a successful implementation of these two IT-based learning environments into an international marketing class. Hereby, factors which are most relevant for the successful introduction of each technology type will be identified. Finally, recommendations for instructors based on the evaluation of the results of the study and implications for practitioners and policy makers are provided. 


\section{STUDENT SATISFACTION WITH IT-BASED LEARNING ENVIRONMENTS}

As students are ultimately the receivers of teaching or in the marketing term "customers" (Gummesson, 1999), which is frequently applied to educational delivery (Simpson \& Siguaw, 2000), their satisfaction is frequently used to measure the effectiveness of learning environments (Daly, 2001; Guzley, Avanzino, \& Bor, 2001; Piccoli, Ahmad, \& Ives, 2001; Simon et al., 2003). Student satisfaction measures have been used to predict results and discover user perceptions and training effectiveness (Simon, 2000). Satisfaction itself is created by the difference between expectations and experiences of learners (Arbaugh, 2001). Students have certain expectations about the learning outcome of courses/course units. These expectations can differ from the actual experiences in the classroom. Obviously, if there are significant discrepancies between classroom experiences and their expectations, dissatisfaction may occur. Conversely, students will be satisfied with the teaching experience (Pearson \& Chatterjee, 2000). In the following subsections, the antecedents of students' satisfaction of IT-based environments for international marketing teaching are presented. Figure 1 summarizes these influential factors, which will be detailed below.

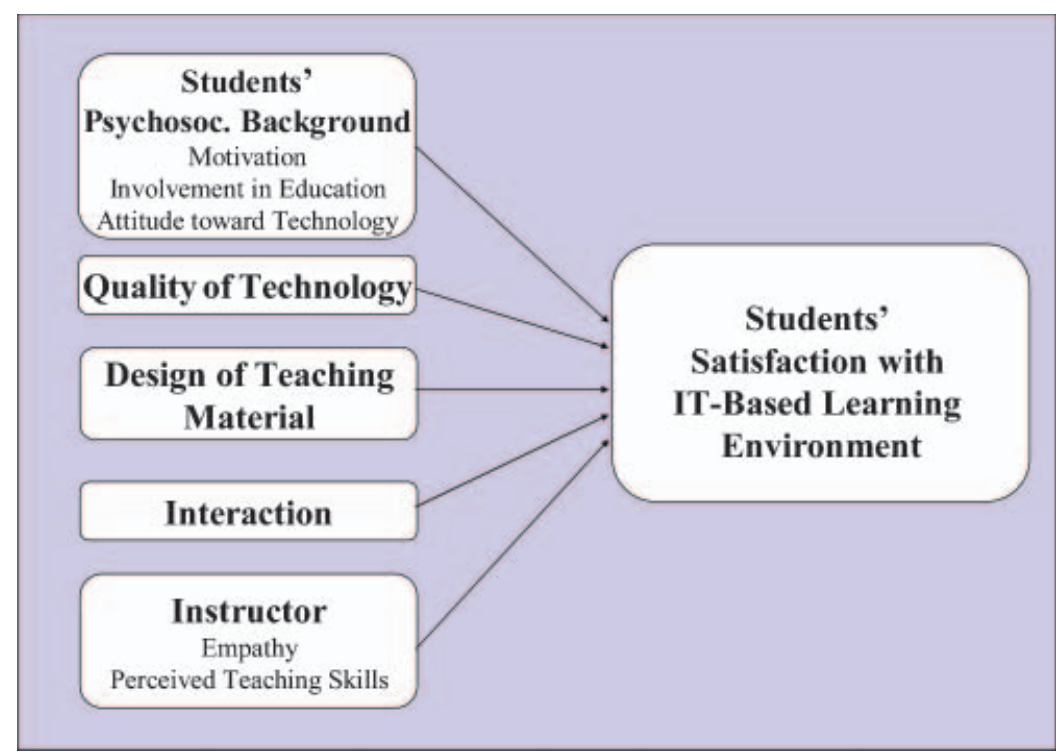

FIGURE 1 Students' Satisfaction With IT-based Learning Environments. 


\section{Students' Psychosocial Background}

Student motivation. Students are more likely to make sense of learning resources and instruction when they are intrinsically motivated (Rust, 2002). In the case of international marketing curriculum, motivation itself has many influence factors. They include industrial international marketing experience of the instructor(s) as they can bring experiential as well as theoretical knowledge to intrigue students, curricula design which can link the needs of industries with learning outcomes of the students, and personal involvement of the students in that they are exposed to key marketing theories and given opportunities to put them into practice (such as through case studies where they can learn about how to market across diverse cultures; Crittenden, 2005; Crittenden \& Dickson, 2005). When these factors are taken into consideration, it is more likely that students are better motivated. This in turn encourages them to identify their own questions, goals, and issues that arise through emerging themes of discussions in the international marketing learning environment (Mumford, 1997). Clearly, the relationship between motivation and learning is important and has long been addressed in classroom teaching (Hunt et al., 2004). This relationship in the traditional classroom teaching of international marketing can be extended to the ITbased learning environment just as well. This is because, while traditional classroom teaching tends to rely on case studies for learning of practical knowledge, technology is suggested to act as another supportive instrument which exposes students to experiential learning about the international marketplace (Alon, 2003). This in turn leads to student satisfaction (Guzley et al., 2001).

Student involvement in education. Traditionally, students are characterized by various level of involvement in learning and differ in their involvement in different learning environments. More specifically, it has been observed that learning in a more challenging environment is more effective for highly involved learners (Hiltz, 1993; Hunt, Eagle et al., 2004). When exposed to an IT-based learning environment, learners are confronted with new challenges (Song et al., 2004), such as in the international marketing curriculum. Technology may be dominating the classroom at first and require learners to react appropriately within this new context. Involved learners show a better understanding of the teaching experience they consume, which leads to a more positive learning experience (Hunt et al.; McKeachie, 1994). In other words, highly involved international marketing students are more willing to be challenged by the use of IT and to attempt to better understand the offering of IT-based learning as another channel of

gaining knowledge. It can, therefore, be assumed that high involvement of learners contributes to their satisfaction with the teaching experience. In the 
context of international marketing learning environment, students who are highly active in learning theoretical and experiential knowledge are more likely to find positive experience with the IT used.

Student attitude toward technology. Today's students are growing up in a world that is increasingly interactive, technology based, and communication intensive (Ueltschy, 2001). They bring to the learning setting a range of experiences, expectations, and values which are substantially different from those held by students of earlier generations. Proserpio and Gioia, (2007) viewed this generation as the virtual generation as they are much more accustomed to a "lonely" search mode and value this search style as a desirable hallmark of cyberspace reality. These developments have led to new and conflicting demands on universities/business schools (Akerlind \& Jenkins, 1998). While the earlier generations were less concerned about international dimensions and IT-facilitated learning due to the state of the world at the time, students of recent years are ever more serious about learning about the international dimension of marketing and gaining international experience (such as the emerged phenomenon of studying abroad; Ault \& Martell, 2007). The use of IT to facilitate more experiential learning opportunities are reflected in the modern marketing classroom where communication is more prominently mediated by technology than ever (Celsi \& Wolfinbarger 2002; Ferrell, 1995). In such learning environments, learners who are comfortable with technology and who demonstrate positive attitudes toward IT should thrive due to low levels of anxiety and unfamiliarity, and likely excitement with the learning environment (Hunt et al., 2004; Piccoli et al., 2001). Students with little experience in using IT may show some anxieties and certain reluctance. In line with this, Sturgill, Martin, and Gay (1999) and Hong (2002) state that learners with low IT skills will experience a higher degree of frustration when being exposed to an ITbased learning environment than learners with higher IT skills. Hence, attitudes of students towards IT-based learning environment can play a key role in influencing their learning experience.

\section{Quality of Technology}

Using the applied technology effectively can be of major importance in the IT-mediated international marketing learning environment, because the technology can decrease the distance between learners and instructors (May, 1997; Peterson et al., 2002), enhancing the learning environment. While traditional classroom teaching is more reliable and that technology quality is not of major concern, the growing use of IT in modern international marketing curriculum means that quality issues can have immediate effect on students' learning experience (McCorkle, Alexander, \& Reardon, 2001). Webster and Hackley (1997) suggested that when students perceive used IT 
is of high quality, they tend to show more positive learning outcomes. Technological quality issues often reside in the heart of IT systems and their administrators, and thus outside the organizational realm of instructors. Quality problems may lead to significant delays in schedules and in the curricula, and impatience and frustration from students. As Alavi et al. (1997) and Song et al. (2004) point out, the reliability of software and hardware may prove to be the major disadvantage in IT-mediated teaching, since increasing technological sophistication increases dependency on the technology and raises potential quality concern. Consequently, high levels of technological quality of IT-based learning environments will show a positive influence on students' satisfaction.

Design of teaching material. IT-based learning environments support marketing teaching by means of technological solutions. These instruments are mainly designed to transmit codified information more efficiently, not necessarily the content of a marketing course. Hence, "traditional" teaching material must not be abandoned, but adapted to the technological environment (Song et al., 2004). Design of teaching material refers to quality of the teaching material used in the IT-based learning environment. Its relevance is based on the fact that incomprehensible teaching materials with unclear work assignments reduce the motivation of learners to prepare and participate in a discussion (Tsichritzis, 1999). For international marketing and business students, while IT facilitates experiential learning across cultures by developing a collaborative and high involvement environment for students and instructors, it is noted that high quality materials/literature must be developed to complement the IT-based learning environment (Alon, 2003; Rusinko, 2003). Johnston and McCormack (1996) point out, that the quality of teaching material is often forgotten in the process of ITenabling course content. They highlight the need of educationally sound and user-friendly teaching material. In an IT-based learning environment teaching material refers to the design of technological tools such as computer simulations and web-based courses, or teaching material used where IT is the major means of knowledge transmission (e.g., video conferences).

Course interaction. Generally, interaction in a classroom is a form of personal contact/communication between students and their instructor, or among students (Guzley et al., 2001), where Bork (1995, p. 232) argues that a "high level of interaction is critical of the individualization of learning." On the other hand, Guzley and colleagues (2001) enforce the view that modern technology appears very promising to maximize interaction between instructors and students. Particularly, in the international marketing learning environment, while traditional interaction takes place in a small class of students in the same location, IT allows the class to expand far beyond their 
traditional boundaries of the classroom, university, region, or country (Rusinko, 2003). Hence, a more collaborative learning environment is created where lively interaction keeps a higher level of learning interest among students, as interactivity implies continuous action (Benbunan-Fich \& Stoever, 2003; Petters, 2000). Technology also has a strong impact on the interactions in the classroom. Interaction is a necessary prerequisite of technology-based learning environment, but can also be enhanced by the use of educational technology. In an IT learning environment, students can be more interactive when the class is kept to a reasonable size to allow them to interact with as many other students as possible to build a community.

\section{Instructor}

Instructor empathy. Instructor's empathy plays a crucial role in an IT-based learning environment (Fredericksen, Picket, Shea, Pelz, \& Swan, 2000; Piccoli et al., 2001). Empathy refers to the instructors' skills in sensing the students' needs and responding to them. In teaching international marketing, their empathy is essential as the IT integration efforts may sometimes create stress and anxiety for students. Instructors have to mitigate stressful situations and demonstrate a higher degree of support than in conventional classes. Moreover, as noted by Proserpio and Gioia (2007), in comparison to traditional collaborative learning environment where students develop interpretations and personal solutions to a given problem-solving situation, instructors need to realize that IT can make students feel a degree of anonymity or at least a lack of nonverbal cues. As students may feel more isolated, they seek more contact with instructors outside of normal hours. Instructors must be able to sense and respond to the demand by devoting more time and efforts than in the traditional classroom environment (Piccoli et al.). High personal involvement of the instructors can lead to a higher effectiveness of the IT-based learning environments (Piccoli et al.). Lessons provided in an IT-based learning environment thus require a higher amount of social skills and encouragement of students (Leidner \& Jarvenpaa, 1995). Moreover, when instructors sense the presence of ethnocentricity amongst students as they have been confined to a particularly culture, IT-based learning environment can help to reduce such a barrier to achieving international marketing learning outcomes (Fluck, Clouse, \& Shooshtari, 2007).

Perceived teaching skills of instructor. IT-based learning environments create new challenges for the faculty and their teaching processes (Song et al., 2004). Perceived teaching skills refer to all elements of teaching, such as communication of information, information processing, information storing and recall, information application and transfer, and controlling 
and supervising learning (Klauer, 1985). In teaching international marketing, effective instruction means asking the appropriate questions rather than guiding students toward the actual responses, and facilitating the sharing of information (Leidner \& Jarvenpaa, 1995). Receiving detailed information and instructions encourages students and increases their commitment (Snyder, 2003). In an IT-based leaning environment, international marketing educators need to design an appropriate teaching format which focuses on facilitating students to explore and learn marketing in a cross-culture context. This requires instructors to spend more effort in preparing and planning as prior arrangements/liaison must be made with additional personnel which are not necessary in the traditional classroom, including IT personnel and instructors in other locations (Simon et al., 2003). Also, in comparison to traditional face-to-face environment, IT-based teaching requires instructors' attention to student interaction due to the remote feeling. Hence, interactive teaching style is crucial in achieving learning outcomes (Webster \& Hackley, 1997). Instructors need not only to develop a teaching design for the IT-based learning environment, but also an increased involvement with and interest in the technology itself, otherwise, IT is not likely to be properly diffused for teaching. Hence, technological competence and personal interests in IT are particularly important factors of instructor teaching skills in creating a student-oriented learning environment in the international marketing curriculum (McCorkle et al., 2001).

\section{A Comparison of IT-based Learning Environments}

In the modern marketing classroom, there are two predominant forms of IT innovations (Bell et al., 2001; Jennings, 2002; Simon et al., 2003) which will be specifically addressed at in this article:

- creating virtual classrooms by connecting dispersed groups of audience via video conferencing; and

- using computer-based marketing simulations to expose learners to artificial markets and business environments.

The following two sections are dedicated to the investigation of the educational opportunities of each of these technological tools.

Video conferencing-based learning environments. A video conferencing-based learning environment refers to two or more higher education institutions that are geographically dispersed and which communicate via a video conference system (Klein et al., 2001). A video conferencing-based learning environment has the following distinctive properties:

- Two or more learner-instructor teams are geographically dispersed. 
- Knowledge and content are available from multiple sources, apart from the local instructor.

- Direct and symmetric interaction is available between all combinations of remote and local instructors and learners.

- A combination of media may be deployed. (Multisite) video conferencing supports symmetric and synchronous communication. Additional educational materials, such as slides, printed case studies, and video recordings may be incorporated into the teaching (Simon et al., 2003).

In such learning environments, learners and instructors are able to take advantage of IT in order to overcome distance. It has been widely accepted that video conferencing-based learning environments-also referred to as virtual classrooms - add value by enriching the learning environment, particularly in international settings (Alavi et al., 1997; Bell et al., 2001; Pallab \& Kaushi 2001; Simon et al., 2003; Webster \& Hackley, 1997).

International marketing course enrichment can be seen at various levels. Dede (1990) and Peterson et al. (2002) state that this learning environment is opening up new opportunities to discover new educational goals and instructional methods that have the potential to reach a wider range of student skills than in the traditional classroom. It also provides opportunities for creating student awareness for international issues and for developing a greater knowledge and understanding of the global business environment (Wymbs \& Kijne, 2003). International dimensions is incorporated swiftly by adopting this kind of learning environment (Bell et al., 2001). The video conferencing-based learning environments can thus broaden learners' perspectives and increase their cross-cultural effectiveness (Arbaugh, 2000; Benbunan-Fich and Stoever, 2003; May, 1997). Students and instructors with different sociocultural and educational backgrounds bring a host of different ideas, experiences, and distinctive management assumptions and practices to the (virtual) classroom (Ashamalla, 1999). This diversity offers great potential for enriching modern marketing courses consisting of strong international dimension (Simon et al., 2003).

Computer-based marketing simulations. They refer to a type of software, which once implemented, provides an "interactive, computerbased model of a firm in a marketplace, in which students analyse available data, take decisions concerning marketing variables, and then receive results on their performance" (Tonks, 2002, p. 179). Students are able to put their theoretical knowledge into practice through making real life decisions. The outcomes of their decisions can be applicable on more general decision. International marketing simulations allow experience to be gained by handling new situations in an artificial world. For instance, in considering market entry, students are asked to analyze and understand data (Feick, Roth, Deighan, \& James, 2003), and make an appropriate decision. Results 
on their performance (Klassen \& Willoughby, 2003) are a function of interaction in the simulated marketplace or virtual environment.

Simulation-based learning environments are learner-centered. Learners can control the pace at which they perform specific tasks. Rather than following lectures in a passive or reactive mode, simulations allow learners to pace the progress themselves (Doyle \& Brown, 2000; Lehtonen \& Haho, 2003; Rosenorn \& Busk, 1998). However, in simulation-based learning environments, instructors still play an important role as facilitators for learning. As compared with real world experiences, marketing simulations have the potential of being more effective (learning is part of the game) and less costly. Simulation processes can be performed quicker than in the real world and thus reduce the amount of time required for gaining experiences (Doyle \& Brown; Härtel \& Lüdke, 1997; Lehtonen \& Haho). Therefore, they allow experience to be gained in handling an unknown situation while avoiding risk and stimulate the discussion of complicated topics, heighten self-awareness, and the examination of one's own behavior (Jennings, 2002; Wolfe, 1976). Acquisition of a wide range of skills becomes so possible, which makes simulations superior in adding realism to learning than other teaching methods (Jennings, 2002).

\section{METHODOLOGY}

To investigate the satisfaction with IT-mediated learning environments, students were surveyed and questionnaires were used to sample their responses. Student evaluations can be used as a very effective diagnostic device to separate effective teaching techniques from the ones which require significant updating or possibly elimination from the classroom (Simpson \& Siguaw, 2000).

Both surveys were conducted at a major business school in Austria in 2002 and 2003. The survey on satisfaction with the virtual classroom was conducted over a 1-year teaching period within which 90 students (46 male, 44 female) participating in an International Marketing class were interviewed. These students were postgraduate (MSc) students and were all actively participating in virtual classroom sessions.

The data on satisfaction with marketing simulations was gathered during a period of 18 months, in which a total of 120 students were interviewed. All students took a marketing case study class, which familiarized them with a computer-based marketing simulation. Fifty-nine of the students interviewed were male, 61 were female. Similarly, the students represented a cohort of postgraduate MSc students.

Students' experiences were captured through questionnaire surveys at the end of the respective marketing courses. The questionnaires were handed to the students by their instructors to ensure every participant's 
opinion was captured in the survey. The questionnaires were administered in English (as was the course unit) and multi-item scales were used to tap into simulation or virtual classroom issues (full scales are available in the appendix). All measures were assessed via a 5-point Likert-type scale ranging from strongly agree to strongly disagree. Table 1 below provides an overview of the scales used in this investigation.

\section{RESULTS AND DISCUSSION}

In order to investigate whether antecedents to learners' satisfaction with ITbased learning environments differed across environments, regression analysis was applied on the metric scales (Hair, Black, Babin, Anderson, \& Tatham, 2006). For both regression analyses, satisfaction was the dependent variable; and independent variables (core factors which contributed to changes in the variance of satisfaction) included in the regression equation were motivation, virtual classroom interaction, empathy, design of teaching material, technology, and teaching skills. The results in Table 2 indicate that the most dominant factors differed between the two IT-based learning environments.

Evidently, the two IT-based learning environments require different antecedents to be successful. With respect to the virtual classroom

TABLE 1 Overview of Scales Used

\begin{tabular}{|c|c|c|c|}
\hline Scale Name & Scale Origin & Virtual Classroom & Simulation \\
\hline Satisfaction & $\begin{array}{l}\text { Satisfaction with Activity by } \\
\text { Fisher and Price (1991) }\end{array}$ & .84 & .84 \\
\hline \multicolumn{4}{|l|}{ Student } \\
\hline Motivation & $\begin{array}{l}\text { Motivation Scale by Andrews } \\
\text { and Smith (1996) }\end{array}$ & .71 & .91 \\
\hline $\begin{array}{l}\text { Involvement in } \\
\text { Education }\end{array}$ & $\begin{array}{l}\text { Involvement with Education by } \\
\text { Arora (1982) }\end{array}$ & .73 & .73 \\
\hline $\begin{array}{l}\text { Attitude toward } \\
\text { Technology }\end{array}$ & $\begin{array}{l}\text { Domain Specific Innovativeness } \\
\text { by Goldsmith and Hofacker } \\
\text { (1991) }\end{array}$ & .74 & .67 \\
\hline $\begin{array}{l}\text { Quality of } \\
\text { Technology }\end{array}$ & Developed by authors & .85 & .75 \\
\hline $\begin{array}{l}\text { Design of Teaching } \\
\text { Material }\end{array}$ & Developed by authors & .70 & .78 \\
\hline Interaction & Developed by authors & .72 & .53 \\
\hline \multicolumn{4}{|l|}{ Instructor } \\
\hline Empathy & Developed by authors & .75 & .78 \\
\hline $\begin{array}{l}\text { Perceived Teaching } \\
\text { Skills }\end{array}$ & $\begin{array}{l}\text { Developed by authors and the } \\
\text { local Teaching Evaluation Team }\end{array}$ & .91 & .90 \\
\hline
\end{tabular}


TABLE 2 Results of Regression Analysis-Core Factors

\begin{tabular}{|c|c|c|c|}
\hline $\begin{array}{l}\text { Independent } \\
\text { Variable }\end{array}$ & $\begin{array}{l}\text { Dependent Variable } \\
\text { Satisfaction Virtual } \\
\text { Classroom }\end{array}$ & $\begin{array}{l}\text { Independent } \\
\text { Variable }\end{array}$ & $\begin{array}{c}\text { Dependent Variable } \\
\text { Satisfaction } \\
\text { Marketing Simulation }\end{array}$ \\
\hline Motivation & $t=2.5$ & $\begin{array}{l}\text { Design of Teaching } \\
\text { Material }\end{array}$ & $t=2.21$ \\
\hline $\begin{array}{l}\text { Virtual Classroom } \\
\text { Interaction }\end{array}$ & $t=2.60$ & Technology & $t=2.57$ \\
\hline Empathy & $t=3.00$ & Teaching Skills & $t=3.34$ \\
\hline Adjusted $R^{2}$ & .26 & Adjusted $R^{2}$ & .247 \\
\hline
\end{tabular}

Note. $t$ values larger than 1.96 in magnitude are significant at $5 \%$. Hence, all independent variables reported above are significant in their contribution to explain the variance of the dependent variable satisfaction.

interaction, the regression points to students' motivation, virtual classroom interaction, and instructor's empathy as the most important factors contributing to success/satisfaction. Contrastingly, in the case of marketing simulations, variables such as design of teaching materials, student motivation, and teaching skills contribute mostly to student satisfaction.

\section{Increasing Students' Satisfaction With the Virtual Marketing Classroom}

Three factors were found to be influencing students' satisfaction with the virtual marketing classroom.

Motivation. Students perceive lectures conducted in the virtual classroom to be extraordinary, of which they will keep in their memories. The differing aspects of the international marketing topics discussed by students at the remote sites are positively perceived by most interviewed participants (Simon et al., 2003). The exposure to different cultures and the opportunities to interact during the lectures on an international basis with universities in foreign countries have a major impact on the positive emotions associated with the lecture.

Despite this positive result, the virtual classroom requires highly motivated learners. The classroom setting is easily mixed-up with the passive watching of TV. Seeing colleagues from behind a camera might encourage tendencies of drifting away and becoming even more passive. Our findings suggest that only those who are motivated to participate in such an undertaking should be assigned right in front of the cameras. However, if instructors were to divide classes into active and passive learners, they might impose a new two-tier role-distribution, reinforced by technology, with negative effects on overall learning effectiveness (Simon et al., 2002).

Virtual classroom interaction. The various international marketing instructors at the different sites are a dominant feature of the virtual classroom, 
because they play a vital role in leading the class discussion. Interaction within the classroom may automatically occur, but effective interaction, which aims at promoting learning, does not (Guzley et al., 2001). Instructors have to coordinate contributions from the local audience as well as from the remote sites. The dialogue between the various instructors also adds to the dynamics of the educational activity and helps to hold students' attention (Tsichritzis, 1999). The need of classroom interaction increases by the number of sites and learners participating in the virtual classroom. Communication which involves various sites and a large number of students naturally create challenges for the instructors. Not all learners can be equally addressed and it is also difficult to hold the attention level of all participants. There is danger that learners will not participate in the discussion and consequently become increasingly less interested observers of the scene (Rosenberg, 2001). The quality of the virtual classroom can, therefore, be enhanced by keeping the group of participating learners small (Guzley et al.). The more sites and learners participate, the more difficult it is to integrate them in a discussion. A higher number of participants, therefore, also lead to longer waiting periods and a lot of listening. It is advisable not to rely on an overly structured design so that interaction among participants of the virtual classroom remains fluid and dynamic. In many cases, instructors-especially when dealing with this technology for the first time-tend to structure the discussion with the foreign partners too rigidly. This involves designating students to present results and ask prepared questions. However, this also involves a higher proportion of passive students in every site. A more lively and spontaneous interaction style among the various sites proves more satisfying when applying the virtual classroom into the marketing curriculum. Students are listening more attentively and contributing actively to a lively discussion with culturally diverse participants.

Empathy. Jackson (2003) reports that students can be divided into two groups. One group represents techno-enthusiasts; the other group is made up of students who see IT in the classroom with some trepidation. Learners who have no prior experience in virtual classrooms are generally very curious about the new environment, but at the same time, demonstrate some anxiety when presenting live in front of an international audience. Instructors' empathy plays an especially important role in the application of the virtual classroom. Students require support and encouragement for highly IT dependent courses (Rosie, 2000). The international marketing classroom is opened to the world, which creates enormous nervousnessespecially when using the virtual classroom for the first time. Instructors are required to coach learners in order to reduce the pressure experienced when presenting to an international audience. This also includes a more intensive preparation of the issues discussed and personal supervision of the presentation materials. Since the virtual classroom mainly take place in 
English it is important to also involve students with less competent English language skills (Simon et al., 2003).

\section{Integrating Computer Simulations into the International Marketing Curriculum}

The three factors influencing satisfaction with computer simulation were design of teaching material, technology, and teaching skills.

Design of teaching material. The design of teaching material is strongly related to the satisfaction of learners when using computer-based marketing simulation. In the case of a marketing simulation, it refers to the design of the computer program. The simulation should be developed in such a manner that it augments information gained through classroom discussion, lecture materials, and text references. Students usually require a brief introduction on the technical aspects of the simulation and will expect the contextual background (purpose of the simulation, overall goals, strategies to be pursued, etc.). Therefore, the software needs to be easy to access and logical and should not distract from the overall learning process. Learners usually find mistakes and inconsistencies in the simulation very quickly. It is, therefore, recommended to use simulations that already have been shown to be successful in international marketing courses and avoid any kind of experiments involving newly developed software packages.

Technology. It is pointed out that technological problems with IT-based learning environments lead to frustration among students (Jackson, 2003; Williams, 2002). Our results support these findings. The technology of the international marketing simulation must be easily understandable and simple to use, where, with a short introduction, students should be able to use the program and understand the program interface without many difficulties. Simulation results should be available quickly and without any delay. Calculations of the simulations should be understandable and fast. Still, when students work with marketing simulation, problems in using the software may appear and lead to lower speed of the learning process. This is because students need to do exercises again and again to achieve reasonable results. The instructor should also be very conscious about using the technology as he or she may be confronted with technological problems experienced by students running the simulations.

Teaching skills. Teaching skills are extremely important when using marketing simulations (Heineke \& Meile, 1995). As outlined, a lack in technological wizardry and content quality can provoke very negative student reactions. Learner guidance, therefore, constitutes an important success factor for simulation-based learning environments (Härtel \& Lüdke, 
1997). A lack of guidance, on the contrary, can cause disorientation and frustration. Heineke and Meile advise instructors to run through the entire simulation before using it in class. The instructor must, therefore, invest a great deal of time, effort, and evaluation to ensure the completeness of the simulation. Marketing educators must be careful not to underestimate the length of time that the successful development of the simulation will take and should be discouraged from using the simulation until the entire scenario is completed. Failure to develop the simulation properly will result in low levels of student motivation and can also foster ineffective or incorrect learning throughout the simulation (Shirts, 1992). An incomplete or poorly thought-out simulation will thus not produce the results desired by either the instructors or the students (Gillentine \& Schulz, 2001).

\section{CONCLUDING REMARKS}

The integration of IT into university classrooms remains a matter of great interest to educators and educational policy makers. This study deals with some of the challenges of IT integration in an international marketing teaching context. Antecedents to successful teaching in two diverse ITbased learning environments are explored and evaluated. A consumer perspective (learner satisfaction) is used to investigate virtual classrooms and computer simulations in their requirements to achieve desired satisfaction outcomes. Results show that antecedents for learners' satisfaction with the virtual classroom and marketing simulation differ. Consequently, requirements for educators with ambitions to integrate these methods in their international marketing classes differ and necessitate appropriate considerations.

For virtual classroom interaction, instructors are encouraged to identify levels of student motivation and involvement and build their teaching strategy around these dimensions. Students who share a tendency of being reserved or passive will require special attention; instructors can use supplementary international marketing and business literature and materials in their classes, to support the virtual learning process. In doing so, students are less likely to lose themselves in front of the screen. They are forced to shift their attention between various learning technologies, by reading, digesting, and discussing materials available to them. It may also be useful that instructors who moderate the virtual classes motivate students by providing opportunities to participate or lead group discussions. Quality of virtual interaction must also be taken into consideration. More specifically, instructors should avoid crowed or large virtual classrooms as these tend to limit student interaction, learning opportunities and feedback options. International marketing education is deemed to expose students to crosscultural dynamics, and should thus build on experiential learning and 
spontaneity. Hence, in the virtual classroom context, instructors who emphasize a relatively loose and flexible atmosphere of constructive discussion and participatory interaction will enrich the learning experience. In terms of applications of computer simulations to international marketing curriculum, instructors should either use simulations which are predesigned to suit the specific course levels or adjust the technology and the learning outcomes appropriately. As technological problems are likely to emerge, instructors are encouraged to develop a certain level of IT competence that does not only enable them to operate the simulations, but also deal with possible technological issues confronted by students. A certain level of enthusiasm from instructors for building IT competence is necessary.

This article has taken a practical approach in furthering current understanding and practice of IT-mediated teaching in the international marketing curriculum. The outcomes have not only provided useful guidance to academics in using IT to create positive learning environments for students, but also created opportunities for employers to recruit competent teaching staff with skills in IT and more practical cross-cultural marketing knowledge beyond pure conceptual knowledge. Moreover, policy makers are offered an understanding where instructor and student support is needed. When educational institutions productively establish ITmediated learning environments, it becomes a strong positive force for all parties concerned.

While it is clear from this study that IT can indeed be a very useful instrument in creating supportive learning environments for students of international market courses, it should not be mistaken as the replacement of traditional classroom interaction or seen as superior of the latter under all circumstances. While traditional teaching methods are arguably less effective in bridging the theory-practice gap in comparison to IT-based learning, these are still more effective in terms of other aspects of international marketing education. For instance, as observations in this study have demonstrated, technological quality issues, potential anxiety and low involvement of students towards IT, IT competence and interests of the instructor, department, school or university are factors which can build barriers to effective teaching. Hence, traditional and virtual learning environments provide both pros and cons and should be seen as complimentary tools in a learning context which fares well when variety and diversity are needed. The fundamental question is not which learning environment is better but how can they be used in international marketing and business curricula to improve teaching that is attuned to learning needs of the modern generation of students.

As with any empirical research, there are limitations with this study. Student satisfaction measures, although enthusiastically adopted by university administrators for measurement and quality control purposes, remain somewhat problematic as source of information on quality of delivery and 
learning outcomes. Students are increasingly overloaded with standardized questionnaires of this type and response bias might pose challenges. As a remedial strategy, observational techniques are suggested. Given that students can be considered a captive audience-e.g., in computer laboratories-observational techniques should be easily deployable. This would provide for a useful alternative to standard questionnaires and help to obtain new insights into student satisfaction and learning outcomes of ITbased marketing teaching. Furthermore, sample from one social context in this study may not represent students from other countries. The findings in this study need to be considered carefully when applying to other contexts as students from different social/economic environments are likely to have differing criteria for satisfaction and experience with IT. Also, status of technologies in a country and education systems may also have some influence. Hence, instructors from other nations may need to pay particular attention to some antecedents than others.

Moreover, there are two recommendations for future studies. First, while this study has focused on providing insights on two widely used IT innovations for teaching international marketing courses, there are other technologies, such as web-based country projects and internet discussion groups (Strauss \& Frost, 1999), which have not been addressed here. It is recommended that future studies should focus on exploring new technologies as they advance. Second, aside from student satisfaction as a useful measure of IT practice in international marketing curriculum, it is also of major interests to academics in terms of whether the two different ITenabled learning environments have potentially different levels of effectiveness in impacting on students' learning outcomes. This is particularly relevant in terms of transferable skills such as communication, critical thinking, team-working, application of knowledge, etc. It is recommended that future studies address this question to gain more insights into the two ITenabled learning environments for effective teaching in the international marketing curriculum.

\section{REFERENCES}

Akerlind, G. S., \& Jenkins, S. (1998). Academics' views of the relative roles and responsibilities of teachers and learners in a first-year university course. Higher Education Research and Development, 17(3), 277-289.

Alavi, M., Yoo, Y., \& Vogel, D. (1997). Using information technology to add value to management education. Academy of Management Journal, 40(6), 1310-1333.

Alderfer, C. P. (2003). Using experiential methods to teach about measurement validity. Journal of Management Education, 27(5), 520-532.

Alon, L. (2003). Experiential learning in international business via World Wide Web. Journal of Teaching in International Business, 14(2-3), 79-98. 
Andrews, J., \& Smith, D. C. (1996). In search of the marketing imagination: Factors affecting the creativity of marketing programs for mature products. Journal of Marketing Research, 33(2), 174-187.

Arbaugh, J. B. (2000). Virtual classroom characteristics and student satisfaction with Internet-based MBA courses. Journal of Management Education, 24(1), 32-54.

Arbaugh, J. B. (2001). How instructor immediacy behaviors affect student satisfaction and learning in web-based courses. Business Communication Quarterly, 64(4), 42-54.

Arora, R. (1982). Validitation of an S-O-R model for simulation, enduring, and response components of involvement. Journal of Marketing Research, 19(4), 505-516.

Ashamalla, M. H. (1999). Directed self-learning: The use of learner-generated cases in international management training. Journal of Teaching in International Business, 11(2), 71-87.

Ault, D. E., \& Martell, K. (2007). The role of international exchange programs to promote diversity on college campuses: A case study. Journal of Teaching in International Business, 18(2-3), 153-177.

Bell, J., Deans, K., Ibbotson, P., \& Sinkovics, R. R. (2001). Towards the 'internetalization' of international marketing education. Marketing Education Review, 11(3), 69-79.

Beller, M., \& Or, E. (1998). The crossroads between lifelong learning and information technology-A challenge facing leading universities. Journal of Computer Mediated Communication, 4(2). Retrieved November 21, 2001, from www.ascusc.org/jcmc/vol4/issue2/beller.html

Benbunan-Fich, R., \& Hiltz, S. R. (1999). Educational applications of Cmcs: Solving case studies through asynchronous learning networks. Journal of ComputerMediated Communication, 4(3). Retrieved November 21, 2001, from www. ascusc.org/jcmc/vol4/issue3/benbunan-fich.html

Benbunan-Fich, R., \& Stoever, W. A. (2003). Using information technology to promote multi-cultural case teaching: A pedagogical framework. Journal of Teaching in International Business, 14(2-3), 13-27.

Blake, I., \& Jarvenpaa, S. L. (1996). Will the Internet revolutionize business education and research? Sloan Management Review, 37(3), 33-41.

Bork, A. (1995). Distance learning and interaction: Toward a virtual learning institution. Journal of Science Education and Technology, 4(3), 227-244.

Catterall, M., Maclaran, P., \& Stevens, L. (1999). Critical marketing in the classroom: Possibilities and challenges. Marketing Intelligence \& Planning, 17(7), 344-353.

Celsi, R. L., \& Wolfinbarger, M. (2002). Discontinous classroom innovation: Waves of change for marketing education. Journal of Marketing Education, 24(1), 64-73.

Clark, I., III, Flaherty, T. B., \& Mottner, S. (2001). Student perceptions of educational technology tools. Journal of Marketing Education, 23(3), 169-177.

Crittenden, V. L. (2005). Cross-functional education: The need for case development. Journal of Business Research, 58(7), 955-959.

Crittenden, V. L., \& Dickson, P. (2005). Cross-functional cases in management education. Journal of Business Research, 58(7), 944-945.

Daly, S. P. (2001). Student-operated Internet businesses: True experiential learning in entrepreneurship and retail management. Journal of Marketing Education, 23(3), 204-215. 
Dede, C. J. (1990). The evolution of distance learning: Technology-mediated interactive learning. Journal of Research on Computing in Education, 22(1), 247-264.

Doyle, D., \& Brown, W. F. (2000). Using a business simulation to teach applied skills-The benefits and the challenges of using student team from multiple countries. Journal of European Industrial Training, 24(6), 330-336.

Feick, L., Roth, M., Deighan, M., \& James, S. (2003). Country manager: The international marketing simulation. Charlottesville, VA: Interpretive Software, Inc.

Ferrell, O. C. (1995). Improving marketing education in the 1990s: A faculty retrospective and perspective view. Marketing Education Review, 5(3), 1-6.

Fisher, R. J., \& Price, L. L. (1991). The relationship between international travel motivations and cultural receptivity. Journal of Leisure Research, 23(3), 193208.

Fluck, U., Clouse, S. F., \& Shooshtari, N. H. (2007). Reducing ethnocentrism in international business students with an online multicultural supplement. Journal of Teaching in International Business, 18(2-3), 133-142.

Fredericksen, E., Picket, A., Shea, P., Pelz, W., \& Swan, K. (2000). Student satisfaction and perceived learning with online-classes: Principles and examples for the SUNY Learning Network. Journal of Asynchronous Learning Networks, 14(2), 7-14.

Garrison, R. (2000). Theoretical challenges for distance education in the 21st century: A shift from structural to transactional issues. International Review of Research in Open and Distance Learning, 1(1), 1-17.

Gillentine, A., \& Schulz, J. (2001). Marketing the Fantasy Football League: Utilization of simulation to enhance sport marketing concepts. Journal of Marketing Education, 23(3), 178-186.

Goldsmith, R. E., \& Hofacker, C. (1991). Measuring consumer innovativeness. Journal of the Academy of Marketing Science, 19(3), 209-221.

Gummesson, E. (1999). Total relationship marketing: from the 4ps-Product, price, promotion, place - Of Traditional Marketing Management to the 30Rs-The thirty relationships-Of the new marketing paradigm. Oxford, UK: Butterworth-Heinemann.

Guzley, R. M., Avanzino, S., \& Bor, A. (2001). Simulated computer-mediated/videointeractive distance learning: A test of motivation, interaction satisfaction, delivery, learning \& perceived effectiveness. Journal of Computer Mediated Communication, 6(3). Retrieved November 21, 2001, from www. ascusc.org/ jcmc/vo6/issue3/guzley.html

Hair, J. F., Black, W. C., Babin, B. J., Anderson, R. E., \& Tatham, R. L. (2006). Multivariate data analysis (6th ed.). Upper Saddle River, NJ: Prentice-Hall.

Härtel, H., \& Lüdke, M. (1997). Integration von Simulationen und Hypertext, Design von Lernmaterial Im Internet-Format (Integration of simulations and hypertext, design of learning material in the internet-format): Institut für Pädagogik der Naturwissenschaften an der Universität Kiel.

Heineke, J., \& Meile, L. (1995). Games and exercises for operations management: Hands-on learning activities for basic concepts and tools. Englewood Cliffs, NJ: Prentice-Hall. 
Herther, N. K. (1997). Education over the web: Distance learning and the information professional. Online, 21(5), 63-72.

Hiltz, S. R. (1993). Learning without limits via computer networks. Norwood, NJ: Ablex Publishing Corporation.

Hong, K. S. (2002). Relationships between students' and instructional variables with satisfaction and learning from a web-based course. Internet and Higher Education, 5(3), 267-281.

Hunt, L., Eagle, L., \& Kitchen, P. J. (2004). Balancing marketing education and information technology: Matching needs or needing a better match? Journal of Marketing Education, 26(1), 75-88.

Jackson, P. (2003). Ten challenges for introducing web-supported learning to overseas students in the social sciences. Active Learning in Higher Education, 4(1), 87-106.

Jennings, D. (2002). Strategic management: An evaluation of the use of three learning methods. The Journal of Management Development, 21(9-10), 655-665.

Johnston, S., \& McCormack, C. (1996). Integrating information technology into university teaching: Identifying the needs and providing the support. The International Journal of Educational Management, 10(5), 36-42.

Klassen, K., J., \& Willoughby, K. A. (2003). In class simulation games: Assessing student learning. Journal of Information Technology Education, 2, 1-13.

Klauer, K. J. (1985). Framework for the theory of teaching. Teaching \& Teacher Education, 1(1), 5-17.

Klein, M., Gauthier, V., Mayon-White, W., \& Rajkovic, V. (2001). Developing synergies between faculty and students of European business schools through telecommunications and computer supported cooperative tools. Proceedings of 14th Bled Electronic Commerce Conference (Paper 15), Bled, Slovenia.

Kolb, D. A. (1984). Experiential learning: Experience as the source of learning and development. Englewood Cliffs, NJ: Prentice-Hall.

Lehtonen, J-M., \& Haho, P. (2003). Experimental learning through a simulation game in teaching of product management. International Workshop of the IFIP WG 5.7: Experimental Learning in Industrial Management, Aalborg, Denmark.

Leidner, D. E., \& Jarvenpaa, S. L. (1995). The use of information technology to enhance management school education: A theoretical view. MIS Quarterly, 19(3), 265-291.

Manning, R. D., Cohen, M. S., \& DeMichiell, R. L. (2003). Distance learning: Step by step. Journal of Information Technology Education, 2(1), 115-130.

May, B. E. (1997). Curriculum internationalization and distance learning: Convergence of necessity and technology. Journal of Teaching in International Business, 9(1), 35-50.

McCorkle, D. E., Alexander, J. F., \& Reardon, J. (2001). Integrating business technology and marketing education: Enhancing the diffusion process through technology champions. Journal of Marketing Education, 23(1), 16-24.

McKeachie, W. (1994). Teaching tips: Strategies, research, and theory for college and university teachers. Lexington, MA: D. C. Heath and Company.

Meier, P., \& Simon, B. (2000). Reengineering undergraduate teaching by introducing Internet-based learning information systems. In H. R. Hansen, M. Bichler, \& H. Mahrer (Eds.), Proceedings of the 8th European Conference on Information Systems, July 3-5. Vienna, Austria: Springer. 
Middleton, B., \& Long, G. (1990). Marketing skills: Critical issues in marketing education and training. Journal of Marketing Management, 5(3), 325342.

Mumford, A. (1997, Autumn/Fall). When to use the case method. Newsletter of the European Case Clearing House, pp. 16-17.

O'Brien, E. M., \& Deans, K. R. (1995). The position of marketing education: A student versus employer perspective. Marketing Intelligence E Planning, 13(2), $47-52$.

Pallab, P., \& Kaushi, M. (2001). Using information technology for active learning in international business education. Marketing Education Review, 11(3), 8188.

Pearson, C. A. L., \& Chatterjee, S. R. (2000). Outcome expectations and learning effectiveness in an internationally oriented classroom: A qualitative assessment. Journal of Teaching in International Business, 12(1), 61-78.

Peterson, R. A., Albaum, G., Munuera, J. L., \& Cunningham, W. H. (2002). Reflections on the use of instructional technologies in marketing education. Marketing Education Review, 12(3), 7-17.

Petters, O. (2000). Digital learning environments: New possibilities and opportunities. International Review of Research in Open and Distance Learning, 1(1), $1-19$.

Piccoli, G., Ahmad, R., \& Ives, B. (2001). Web-based virtual learning environments: A research framework and a preliminary assessment of effectiveness in basic IT skills training. MIS Quarterly, 25(4), 401-426.

Proserpio, L., \& Gioia, D. A. (2007). Teaching the virtual generation. Academy of Management Learning E Education, 6(1), 69-80.

Rosenberg, M. J. (2001). E-learning-Strategies for delivering knowledge in the digital age. New York: McGraw-Hill.

Rosenorn, T., \& Busk, K. L. (1998). Reflection in learning processes through simulation/gaming. Simulation and Gaming, 29(4), 432-440.

Rosie, A. (2000). Deep learning. Active Learning in Higher Education, 1(1), 45-59.

Rusinko, C. A. (2003). Adapting to the online teaching environment: Using literature to develop experiential exercises for international management. Journal of Teaching in International Business, 14(2-3), 133-145.

Russow, L. C. (2003). Digitization of education: A panacea? Journal of Teaching in International Business, 14(2-3), 1-11.

Rust, C. (2002). The impact of assessment on student learning. Active Learning in Higher Education, 3(2), 145-158.

Scheuermann, F., Larsson, K., \& Toto, R. (2001). Designing collaborative teaching and learning in virtual environments for large scale international participation. In C. Montgomerie \& J. Viteli (Eds.), Proceedings of Ed-Media 2001. Tampere, Finland: AACE.

Schulman, A. H., \& Randi, L. S. (1999). Learning in an online format versus an inclass format: An experimental study. Technological Horizons In Education, 26(11), 54-56.

Schutte, J. G. (Ed.). (1999). Virtual teaching in higher education: The new intellectual superhighway or just another traffic jam? Retrieved January 25, 1999, from www.csun.edu/sociology/virexp.htm 
Shirts, G. (1992). Ten secrets of successful simulations. Training, 3(2), 79-83.

Simon, S. J. (2000). The relationship of learning style and training method to enduser computer satisfaction and computer use: A structural equation model. Information Technology, Learning, and Performance Journal, 18(1), 41-59.

Simon, B., Haghirian, P., \& Schlegelmilch, B. B. (2002). Case study teaching via collaborative information technology. In S. Wrycza (Ed.), Proceedings of the 10th European Conference on Information Systems. Gdansk, Poland. Retrieved April 1, 2009, from www.wu-wien.ac.at/usr/wi/bsimon/publikationen/ CaseStudyTeachingVialT.pdf

Simon, B., Haghirian, P., \& Schlegelmilch, B. B. (2003). Enriching global marketing education with virtual classrooms-An effectiveness study. Marketing Education Review, 13(3), 27-39.

Simpson, P. M., \& Siguaw, J. A. (2000). Student evaluation of teaching: An exploratory study of the faculty response. Journal of Marketing Education, 22(3), 199-213.

Smart, D. T., Kelley, C. A., \& Conant, J. S. (1999). Marketing education in the year 2000: Changes observed and challenges anticipated. Journal of Marketing Education, 21(3), 206-216.

Snyder, K. D. (2003). Ropes, poles, and space: Active learning in business education. Active Learning in Higher Education, 4(2), 159-167.

Song, L., Singleteon, E. S., Hill, J. R., \& Koh, M. H. (2004). Improving online learning: Student perceptions of useful and challenging characteristics. Internet and Higher Education, 7, 59-70.

Strauss, J., \& Frost, R. D. (1999). Selecting instructional technology media for the marketing classroom. Marketing Education Review, 9(1), 11-20.

Sturgill, A. M., Martin, W., \& Gay, G. (1999). Surviving technology: A study of student use of computer-mediated communication to support technology education. International Journal of Educational Telecommunications, 5(3), 239-259.

Tonks, D. (2002). Using marketing simulation for teaching and learning: Reflections on an evolution. Active Learning in Higher Education, 3(2), 177-194.

Tsichritzis, D. (1999). Reengineering the university. Communications of the ACM, 42(6), 93-100.

Ueltschy, L. C. (2001). An exploratory study of integrating interactive technology into the marketing curriculum. Journal of Marketing Education, 23(1), 63-72.

Webster, J., \& Hackley, P. (1997). Teaching effectiveness in technology-mediated distance learning. Academy of Management Journal, 40(6), 1282-1309.

Williams, P. (2002). The learning web: The development, implementation and evaluation of Internet-based undergraduate materials for the teaching of key skills. Active Learning in Higher Education, 3(1), 40-53.

Wolfe, J. (1976). Correlates and measures of the external validity of computer-based business policy decision-making environments. Simulation and Game, 7, 411438.

Wymbs, C. \& Kijne, H. (2003). Digital technology in teaching international business: Is a tradeoff between richness and reach required? Journal of Teaching in International Business, 14(2-3), 29-40.

Young, J. R. (2000). Moving the seminar table to the computer screen. The Chronicle of Higher Education, 46(44), A33. 


\section{APPENDIX}

\section{Survey Questions-Selected Scale Items}

Instructions. Teaching case studies through simultaneously linking students and instructors from different universities via the internet is a path-breaking experience. Consequently, we are interested in finding out how you perceived this experience. Thus, we kindly ask you for your support in assessing our recent joint educational activity by completing this questionnaire.

Section 1: Effectiveness of the Educational Activity-1.1 Satisfaction (1 to 5). Please rate how you have been satisfied with the educational activity. What overall rating do you give to this educational activity? $(1=$ excellent, 5 $=$ terrible)./How enjoyable did you find this educational activity? $(1=$ stimulating, 5 = boring)./Given your current state of knowledge, estimate how relevant the educational activity is to your future career ( $1=$ relevant, 5 $=$ irrelevant)./This educational activity had many unique or special moments $(1=s a$ [strongly agree], $5=s d=$ [strongly disagree])./ This educational activity had special meaning to me $(1=s a, 5=s d)$./This educational activity was as good as expected $(1=s a, 5=s d)$./This educational activity was satisfying to me $(1=s a, 5=s d)$./This educational activity stands out as one of my best learning experiences $(1=s a, 5=s d)$./ This educational activity was worth the effort $(1=s a, 5=s d)$. 1.2: Perceived teaching performance ( 1 to 5, $1=$ strongly agree, $5=$ strongly disagree). The virtual presence of foreign classes was a motivating factor./Using information technology to facilitate learning was a motivating factor./ Communicating in a foreign language was a motivating factor./The virtual presence of the foreign classes was a hindering factor for learning./The information technology used was a hindering factor for learning./ Communicating in a foreign language was a hindering factor for learning.

Section 2: Instructor-Controlled Teaching Environment-2.1:Educational Material Used. This section relates to the material (e.g., case study, textbook, handout) used in the context of this educational activity ( $1=$ strongly agree to $5=$ strongly disagree)./The recommended reading contributed to a better understanding./The educational material (case study, textbook, handout, etc.) used provided excellent support for learning./The educational activity was excellently supported by presentational aids. 2.2:Empathy. Please rate whether the instructors exhibited understanding and concern $(1=s a$ to $5=$ $s d$ ). The instructors listened to problems./The instructors did not pay enough attention to the class./The instructors understood what the class wanted./ The instructors explained the work to be performed./The instructors were polite./The instructors were helpful./The instructors were friendly. 2.3:Interaction Design. This section relates to the flow of information between the instructors and the learners involved in the educational activity 
$(1=s a$ to $5=s d)$. The lack of familiarity with the instructors of the other universities was a problem./The lack of familiarity with the learners of the other universities was a problem./The importance of certain key aspects was appropriately emphasized./The quality of feedback to the learners' comments was excellent./The interaction among the participating parties was too thoroughly planned in advance./There was adequate interaction among all participants. 2.4:Perceived Teaching Skills of Instructors. The academic staff was enthusiastic./The academic staff explained concepts effectively./The academic staff was able to stimulate interest in the subject area./The academic staff communicated clearly./Overall, the academic staff was excellent.

Section 3: Technology. This section relates to the technology used for connecting the participating universities into one virtual classroom. The technology used was clearly explained to me in advance $(1=s a$ to $5=s d)$./I felt comfortable with the technology used $(1=s a$ to $5=s d)$./Overall, the quality of the technology used was $(1=$ much better than experienced to 5 = much worse than experienced)./The video quality of the technology used was $(1=$ much better than experienced to $5=$ much worse than experienced)./The sound quality of the technology used was ( $1=$ much better than experienced to $5=$ much worse than experienced).

Section 4: Learner Profile-4.1:Motivation Toward Learning With Case Studies $(1=s a$ to $5=s d)$. I feel a real sense of accomplishment when I come up with a good solution for a case study/Creating good solutions for a case study is challenging./I don't especially enjoy coming up with a good solution for a case study./Developing solutions for a case study is one of my least favourite tasks. 4.2: Involvement With Education in General ( $1=s a$ to $5=s d$ ). I believe in studying hard to get good grades./I am not the one to be satisfied with an average grade./I am constantly involved in studying to become a well educated person./I have an active interest in all scholarly things./I like to keep abreast of current events. 4.3:Attitudes Toward Technology $(1=s a$ to $5=s d)$. In general, I am among the first in my circle of friends to know about a new multimedia device when it appears./If I heard that a new multimedia device was available in the store, I would be interested enough to go and look for it./Compared to my friends I own just a few multimedia devices./In general, I am the last in my circle of friends to know the names/brands of the latest multimedia devices./I like to learn about new multimedia devices before other people do. 